Jurnal Kimia Sains dan Aplikasi 23 (1)(2020): 21-27
ISSN: 1410-8917
Jurnal Kimia
Aplikasi
Journal Kimia Sains dan Aplikasi
Journal homepage: http://ejournal.undip.ac.id/index.php/ksa

\title{
Antiglycation and Antioxidant Activity from Methanol Extract and Fraction of Xylocarpus granatum Stem
}

\author{
Intan Noviarni ${ }^{\mathrm{a}, 1}$, Irmanida Batubara ${ }^{\mathrm{b}, 2, *}$, Sastia Prama Putri ${ }^{\mathrm{c}, 3}$ \\ ${ }^{a}$ Chemistry Department, Faculty of Mathematics and Natural Sciences, Bogor Agricultural University, West Java, Indonesia \\ ${ }^{\mathrm{b}}$ Tropical Biopharmaca Research Center, LPPM, IPB University, Bogor, Indonesia \\ ${ }^{\mathrm{c}}$ Biotechnology Study Program, Faculty of Engineering, Osaka University, Japan \\ * Corresponding author: ime@apps.ipb.ac.id \\ https://doi.org/10.14710/jksa.23.1.21-27
}

Article Info

Article history:

Received: $4^{\text {th }}$ October 2019 Revised: $30^{\text {th }}$ December 2019 Accepted: $31^{\text {st }}$ December 2019 Online: $31^{\text {st }}$ January 2020

Keywords:

advanced glycation end products; antioxidants; DPPH; Xylocarpus granatum

\begin{abstract}
The objective of this research was to determine the antioxidant and antiglycation activity of methanol crude extract of Xylocarpus granatum stem and its fraction. The methanol crude extract was fractioned by liquid-liquid extraction to obtain three fractions, which were n-hexane fraction, ethyl acetate fraction, and methanol fraction. Antioxidant activity was performed using scavenging 2,2-diphenyl-1picrylhydrazyl (DPPH). The antiaging activity was identified based on the ability to inhibit the formation of advanced glycation end products (AGEs). The results of the study showed that methanol crude extract and all fractions had an antioxidant and antiglycation activity that significantly different from each other $(\mathrm{P}<0.05)$. The results show that the most active antiglycation and antioxidant activity was the methanol fraction with $\mathrm{IC}_{50}$ were $71.55 \mathrm{ppm}$ and $8.52 \mathrm{ppm}$, respectively. The methanol fraction contained an alkaloid, flavonoid, phenolic, and triterpenoid compounds. Subsequent fractionation of the methanol fraction guided by bioassay showed that sub-fraction 1 had the best antiglycation and antioxidant activity. Based on the color of the chromatogram obtained at UV $366 \mathrm{~nm}$, the chemical component contained in the most active fraction was the flavonoid group.
\end{abstract}

\section{Introduction}

Aging is a physiological process that occurs in all living things in all organs of the body. Aging occurs because of free radicals and advanced glycation end products (AGEs), which is the final product of the protein glycation reaction between amino acids and reducing sugars in the body [1]. AGEs contribute to aging through 3 primary mechanisms: 1) AGEs cross-link with the major connective tissue matrices (such as elastin and collagen) found in the dermis and keratin layers in the epidermis layer of the skin resulting in a decrease in elasticity, dryness, and shrinkage of the skin $[2,3]$; 2) AGEs can block the entry of proteasome nuclei in the UbiquitinProteasome System (UPS). The proteasomes consist of two main parts, two outer $\alpha$-rings for binding to the substrate and two inner- $\beta$ rings that are responsible for proteolytic activity [4]. Structured AGEs can inhibit the entry of the proteasome nucleus, which is responsible for the degradation of short-lived and not folded oxidized proteins, consequently, an increase in oxidized and damaged proteins, triggering protein modification $[4,5]$ and; 3) AGEs will also interact with cellular receptors (RAGE). RAGE regulates several essential cellular processes such as inflammation, apoptosis, ROS signaling, proliferation, autophagy, and aging. The interaction between AGE and RAGE changes the function of cells and organs mainly through inflammatory molecules, which cause aging [5, 6]. AGEs produce free radicals upon free radicals, AGEs and other factors accelerate the reaction of protein glycation so that it will 
accelerate aging $[2,7]$. To overcome aging, especially premature aging, antiaging compounds are needed.

Antiaging compounds are expected to be compounds that can neutralize free radicals such as antioxidants and compounds that can inhibit glycation reactions. Antioxidants can ward off free radicals and stop the chain reactions that can damage essential macromolecules in the body [8]-one source of antiglycation and antioxidants contained in plants.

Xylocarpus granatum is a type of mangrove plant that has been used traditionally by coastal women as a traditional powder for skincare [9]. This plant is reported to have strong antioxidant activity that can counteract the free radicals. The methanol extract of $X$. granatum rind has shown to inhibit tyrosinase activity and had potential as an antioxidant agent [9]. The skin of $X$. granatum has secondary metabolites in the form of phenolic, alkaloids, steroids, tannins, triterpenoids, and flavonoids [9, 10, 11, 12]. Not only the skin of the fruit, but the stem also has the potential to be a whitener, because it can inhibit tyrosinase that plays a role in melanin synthesis in melanocyte burning. It is also a source of antioxidants, and the result is that the stem section of $X$. granatum has the highest antioxidant activity and tyrosinase inhibitors $[9,10,11]$. Therefore, this research is focused on the stem of $X$. granatum. Natural antioxidant compounds from plant phenolic groups can inhibit premature aging of skin [13]. However, there have been no reports of antiaging activity on $X$. granatum stems. The purpose of this study was to determine the antioxidant and antiglycation activities of $X$. granatum crude methanol extracts and their fractions; the fraction was obtained from coarse methanol fraction of $X$. granatum stem using liquid-liquid extraction to obtain three portions, which were n-hexane fraction, ethyl acetate fraction, and methanol fraction. In addition, this study also aims to identify secondary metabolites that act as antioxidants and antiglycation.

\section{Methodology}

\subsection{Materials and Tools}

The materials used in this study were $X$. granatum, ethyl acetate, chloroform, methanol, toluene, n-hexane, $\mathrm{DPPH}$, ascorbic acid, BSA (Bovine serum albumin) (Merck), phosphate buffer 0.2 M pH 7.4, glucose (Merck), fructose (Merck), and aminoguanidine (Sigma Aldrich). The instruments used in this study were oven, fluorometry (FluoroSTAR BMG LABTECH), multiplate reader (Iwaki), TLC vessels, chromatographic columns, G60F254 silica gel plates from Merck and commonly used glass tools.

\subsection{Simplicia Preparation}

$X$. granatum samples were from Bengkagi Village, Tojo Una-Una, Togean Islands, Southeast Sulawesi. The samples were determined in the LIPI Cibinong laboratory. The stems are cut into pieces, put into the oven for two days at $40^{\circ} \mathrm{C}$ to dry, then mashed to a powder (simplicia).
The simplicia was analyzed for water content and ashed using the AOAC method.

\subsection{Maceration Extraction}

A total of $3 \mathrm{~kg}$ of Simplicia was macerated with methanol $(10 \mathrm{~L})$ for three times of 24 hours. The macerate was then filtered and concentrated with a rotary evaporator at $30^{\circ} \mathrm{C}$.

\subsection{Phytochemical Test}

Phytochemical tests on samples qualitatively include the identification of alkaloids, saponins, triterpenoids/steroids, flavonoids, and phenolics, according to Harborne [14]. The standard used refers to Adawiah [15].

\subsection{Multilevel Fractionation}

The antiglycation method referred to Povichit et al. [16] with a slight modification. The reaction consisted of a solution containing $0.2 \mathrm{M}$ phosphate buffer ( $\mathrm{pH} 7.4)$, BSA (20 mg/mL), glucose (235 mM), fructose (235 mM), and samples mixed in a test tube. As for the correct solution, distilled water was added as a substitute for glucose and fructose. The control solution was added with distilled water as a substitute for the sample and aminoguanidine as a positive control. The whole solution was incubated for 40 hours at $60^{\circ} \mathrm{C}$, and then the fluorescent intensity was measured using a fluorimeter with an excitation wavelength of $330 \mathrm{~nm}$ and an emission of $440 \mathrm{~nm}$. Antiglycation activity was measured using the following equation:

$$
\text { Inhibition }(\%)=\left|1-\frac{A_{1}-A_{0}}{B_{1}-B_{0}} \times 100 \%\right|
$$

Note:

$A_{1}=$ intensity of fluorescence of sample solution

$\mathrm{A}_{0}=$ intensity of fluorescence of correction sample solution

$\mathrm{B}_{1}=$ intensity of fluorescence of control solution

$\mathrm{B}_{0}=$ Intensity of fluorescence of correction control solution

A regression curve of inhibitory activity calculated the percentage of inhibition of $50 \%\left(\mathrm{IC}_{50}\right)$ to the fluorescence of AGEs.

\subsection{Antioxidant Activity Test}

A total of $100 \mu \mathrm{L}$ of $125 \mu \mathrm{mol} / \mathrm{L}$ DPPH solution was put into a 96 well plate in which there were $100 \mu \mathrm{L}$ of extract/fraction sample. The solution was incubated for 30 minutes at room temperature. The absorbance of the solution was measured at a wavelength of $517 \mathrm{~nm}$ using a multi-well plate reader. The positive control used was ascorbic acid. The percentage of inhibition was determined by measuring the sample absorption and calculated with the formula:

$$
\text { Inhibition (\%) }=\left|1-\frac{A_{\text {sample }}-A_{\text {standard }}}{A_{\text {blank }}-A_{\text {standard }}} \times 100 \%\right|
$$


A regression curve of inhibitory activity calculated the percentage of inhibition of $50 \%\left(\mathrm{IC}_{50}\right)$ of antioxidants.

\subsection{Data Analysis}

All data expressed were as mean \pm SD Data, analyzed using Analysis of Variance (ANOVA), and further tested with Duncan's multiple range test (DMRT) using SPSS version 16.0.

\section{Result and Discussion}

\subsection{Extract Yield and Stem Fraction of X. granatum}

Initial extraction of the $X$. granatum stem was carried out using the maceration method and using methanol as a solvent. The maceration method was chosen so that the sample did not undergo heating, which can damage compounds which could not stand the heat. Methanol was used as an initial solvent because it could dissolve almost all organic compounds, both polar and nonpolar. Methanol molecular structure is $\mathrm{CH}_{3} \mathrm{OH}$, which consists of a polar and nonpolar part. It is polar as it has a hydroxyl group $(-\mathrm{OH})$ and also nonpolar as it has a methyl group $\left(-\mathrm{CH}_{3}\right)$. Methanol has a low boiling point, which makes it easier to evaporate [17]. The moisture content of stem powder of $X$ granatum was $5.80+0.02 \%$. The moisture value was used to correct the yield obtained; hence the yield could be determined based on the dry weight. The yield of methanol extract from the stem of $X$. granatum was $10.66 \%$, this value was obtained from the maceration of $2.8 \mathrm{~kg}$ dried simplicia. The fractionation was continued through liquid-liquid extraction from $X$. granatum stem methanol extract using $n$-hexane solvent obtained by the $10.60 \mathrm{~g}$ fraction, with a green color and a yield of $7.35 \%$ fraction from initial dry weight simplicia (141.3 g). The ethyl acetate fraction was dark red, and the methanol fraction was reddish-brown with the yield shown in Table 1.

Tabel 1 Stem Fractionation Yield of $X$. granatum

\begin{tabular}{ccc}
\hline Fraction & $\begin{array}{c}\text { Extracts Yield } \\
\text { Weight }(\%)\end{array}$ & $\begin{array}{c}\text { Fraction } \\
\text { Color }\end{array}$ \\
\hline $\begin{array}{ccc}n \text {-hexane } \\
\text { Fraction }\end{array}$ & 7.35 & Green \\
Ethyl acetate & 21.30 & Dark Red \\
Fraction & & \\
Methanol & 70.91 & $\begin{array}{c}\text { Brownish } \\
\text { Fraction }\end{array}$ \\
\hline
\end{tabular}

Based on the results of the fractionation, the results obtained varied. This happens due to the different levels of the polarity of each solvent. The higher the extract yield, the higher the substance contained in the raw material.

\subsection{Phytochemical Content}

The principle of the phytochemical content test is the analysis of plant chemical groups with specific testing reagents that provide specific information on certain chemical groups [18]. The more intense color intensity indicates that the extract has a higher level of secondary metabolites.

Table 2. Phytochemical content of $n$-hexane, ethyl acetate, methanol, and crude methanol extract

\begin{tabular}{|c|c|c|c|c|c|c|}
\hline $\begin{array}{l}\text { Phytochemical } \\
\text { test }\end{array}$ & Reagent & 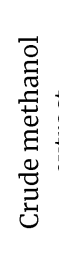 & 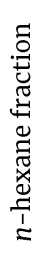 & 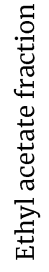 & 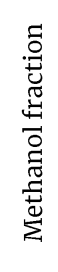 & 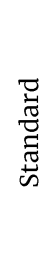 \\
\hline \multirow[t]{3}{*}{ Alkaloid } & Dragendrof & +++ & - & ++ & ++ & +++ \\
\hline & Mayer & +++ & - & ++ & ++ & +++ \\
\hline & Wagner & +++ & & ++ & ++ & +++ \\
\hline Fenolik & Reagent $\mathrm{FeCl}_{3}$ & ++ & ++ & ++ & ++ & +++ \\
\hline Flavonoid & powder $\mathrm{Mg}+\mathrm{HCl}$ & ++ & - & ++ & +++ & +++ \\
\hline Saponin & $\begin{array}{l}\text { Hot distilled water + } \\
\mathrm{HCl}\end{array}$ & - & - & - & - & +++ \\
\hline \multirow[t]{3}{*}{$\begin{array}{l}\text { Triterpenoid/ } \\
\text { Steroid }\end{array}$} & $\begin{array}{c}\text { Reagent Libeberman } \\
\text { Bouchard }\end{array}$ & & & & & +++ \\
\hline & Triterpenoid & ++ & - & + & +++ & +++ \\
\hline & Steroid & - & + & - & - & +++ \\
\hline
\end{tabular}

Note: (-): not detected, (+): detected. Amount of (+) shows the color intensity

Phytochemical content testing showed that only the $\mathrm{n}$-hexane fraction was identified with steroids, and no flavonoids were detected. Flavonoids and triterpenoids are relatively higher in the methanol fraction, which was characterized by a more intense orange color than extracts and ethyl acetate (Table 2).

\subsection{Antiglycation and Antioxidant Activity}

The ability of $X$. granatum extract to inhibit the formation of AGEs was evaluated using antiglycation tests in which the bovine serum albumin acted as a protein, while glucose and fructose as reducing sugars [3]. Antiglycation was determined by determining the amount of AGEs produced by the reaction of proteins (Bovine serum albumin, BSA) with glucose and fructose using fluorimeter [19]. Antiglycation activity was reported with concentrations that could inhibit $50 \%$ of the glycation reaction known as $\mathrm{IC}_{50}$. The smaller the concentration needed to inhibit $50 \%$ of the glycation reaction, the more active the material. The order of antiglycation ability from the strongest was methanol fraction $>$ methanol extract $>$ ethyl acetate fraction $>n-$ hexane fraction (Figure 1). All fractions have possible anti-glycation activity because all fractions contained phenolic compounds. Phenolic compound group derivatives (quercetin, curcumin, ferulic acid, ellagic acid, and iridoids) have significant antiglycation and antioxidant activity [20]. Based on the literature, $X$. granatum has a phenolic group that is dihydrokafeic acid$(3 \rightarrow 8)$-dicatechin, catechin- $(4 \rightarrow 8)$-catechin, kaempferol-3-O-beta-D-glucoside [21, 22, 23, 24, 25, $26,27]$. However, the antiglycation activity in the 
methanol fraction was higher than in the others (Figure 1).

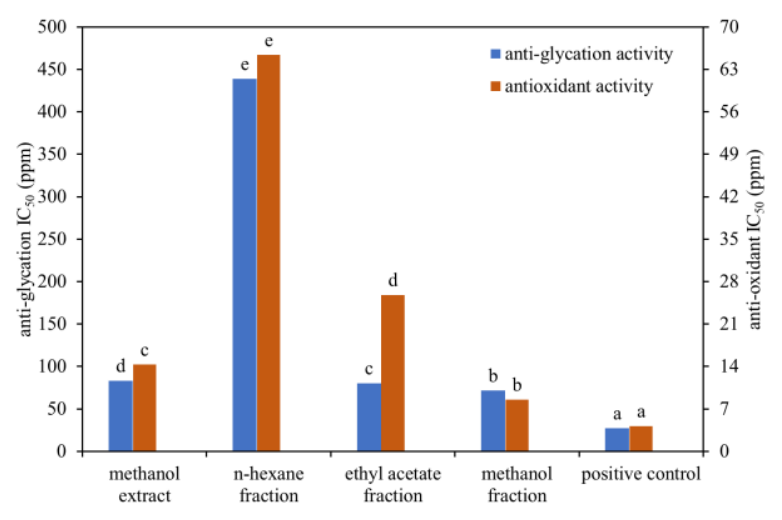

Figure 1. $\mathrm{IC}_{50}(\mathrm{ppm})$ value of antiglycation and antioxidant of extract, $n$-hexane fraction, ethyl acetate, methanol of $X$. granatum stem, and positive control.

Antiglycation is aminoguanidine; antioxidant is ascorbic acid. The letters above of each block of the same color shows the real difference at the level of $(\mathrm{P}<0.05)$, based on Duncan's multiple range test (DMRT)

The value of this antiglycation activity is better when compared to the $\mathrm{IC}_{50}$ amount of antiglycation activity in other plants extracted using methanol, such as Zingiber officinale 203.86 ppm, Curcuma xanthorrhiza 274.14 ppm, Elettaria cardamomum $285.58 \mathrm{ppm}$, Boesenbergia rotunda 274.14 ppm and Curcuma xanthorrhiza 274.14 ppm, Elettaria cardamomum $285.58 \mathrm{ppm}$, Boesenbergia rotunda 274.14 ppm and Bulbocastanumium 132.88 ppm [20, 28, 29]. The best antiglycation activity is in the methanol fraction because, in the methanol fraction, more flavonoids and triterpenoids are detected than other fractions. This is marked by a change in color to a tighter orange and red. Amino guanidine as a positive control has a lower $\mathrm{IC}_{50}$ than that of the methanol fraction because it is a single compound (Figure 1) however, aminoguanidine is not approved for commercial production due to side effects associated with the process of absorption of vitamin B6, drug resistance and hepatotoxicity $[3,30]$.

The presence and activity of antioxidants can be determined through oxidation and reduction reactions using reagents that have chromophores so that they are easily detected using a UV-Vis spectrophotometer. The direct method for detecting antioxidants is 2,2 diphenyl1-picrylhydrazine (DPPH). The principle of the DPPH method is that DPPH captures hydrogen from the reaction of antioxidant compounds and converts it to 2.2 diphenyl-1-picrylhydrazine. DPPH is a stable radical that contains organic nitrogen, with a dark purple color that will turn yellow when reacting with antioxidants, causing a decrease in absorbance value. Testing antioxidant activity using the DPPH method has many advantages because it is stable, does not form dimers caused by delocalization of free electrons in all molecules, does not require substrate so that it is easier and faster analysis time so that the measurement of antioxidant activity can be done accurately [31].
Figure 1 shows that the $\mathrm{IC}_{50}$ antioxidant activity starts from $14.3 \mathrm{ppm}$ to $65.35 \mathrm{ppm}$. The best antioxidant ability is in line with its anti-glycemic ability. The same was also reported in methanol extracts from the stems and roots of Scutellaria alpina $\mathrm{L}$ and Scutellaria altissima $\mathrm{L}$ [3]. The most active antioxidant and antiglycation activity are in the methanol fraction because the methanol fraction contains more flavonoids than the ethyl acetate fraction and the n-hexane fraction. Even in the n-hexane fraction, flavonoids are not detected. Flavonoids inhibit DPPH free radical activity because they can donate proton radicals, which will reduce the formation of non-vertical DPPH [32].

Flavonoids are polar compounds because they have several unsubstituted hydroxyl groups. Therefore, flavonoids are more detectable in more polar solvents. As reported by Haslina and Eva [33], Haslina, the number of flavonoids in corn silk methanol extract was significantly different $(p<0.05)$ compared in ethanol and ethyl acetate extracts. In addition, Maimulyanti and Prihadi [34] states that the antioxidant activity in the methanol extract of Acmella uliginosa is better than ethyl acetate and nhexane extracts

\subsection{Antiglycation and Antioxidant Methanol Fraction Activity}

The continued fractionation of the methanol fraction using the chromatographic column produced a methanol sub-fraction with the results, as shown in Table 3. There was a reduction in DPPH free radical scavenging activity among the sub-fractions compared with methanol extract with significantly different values $(\mathrm{P}<0.05)$. The reduction of DPPH free radical scavenging activity by $X$. granatum extract was better than methanol sub-fraction 2-5 (F2-F5) (Table 3).

That is because the synergy effect of antioxidant compounds is defined as the effect produced by a mixture of two or more types of antioxidants. This effect has a more significant effect than the cumulative effect of the mixture of the two antioxidants. Trang et al. [35] stated that the existence of a synergistic effect that causes antioxidant activity in the ethyl acetate sub-fraction of the stem of Oroxylum indicum Linn is no better than ethyl acetate extract.

The order of strength of the strongest antiglycation activity was F1> F2 $>$ F3 $>$ F5 and $>$ F4 (Table 3). Subfraction 1 of methanol (F1) has the most active antioxidant and antiglycation activity, which is characterized by a low $\mathrm{IC}_{50}$ value. Therefore, F1 was separated again using preparative TLC to obtain three F1 sub-fractions, namely F1.1, F1.2, and F1.3. The separation process in F1 provides a change in activity in F1.1, F1.2, and F1.3 to be less feasible compared to F1 itself. 
Table 3. Antioxidant activity, antiglycation in methanol extract, methanol fraction, and each sub-fraction ( $F 1$, F2, F3, F4, F5, F1.1, F1.2, F1.3, F1.1, F1.2, F1.3) and the yield of $X$. granatum stem.

\begin{tabular}{cccc}
\hline Sample & $\begin{array}{c}\text { Yield } \\
(\%)\end{array}$ & $\begin{array}{c}\text { Antioxidant } \\
\text { activity IC } \\
(\mathrm{ppm})\end{array}$ & $\begin{array}{c}\text { Antiglycation } \\
\text { activity IC } \\
(\mathrm{ppm})\end{array}$ \\
\hline $\begin{array}{c}\text { Methanol } \\
\text { Extract }\end{array}$ & $10.66^{\mathrm{c}}$ & $14.13 \pm 0.16^{\mathrm{c}}$ & $83.23 \pm 0.41^{\mathrm{f}}$ \\
$\begin{array}{c}\text { Methanol } \\
\text { Fraction }\end{array}$ & $70.91^{\mathrm{g}}$ & $8.52 \pm 0.15^{\mathrm{b}}$ & $71.55 \pm 0.37^{\mathrm{d}}$ \\
F1 & $17.83^{\mathrm{e}}$ & $7.58 \pm 0.11^{\mathrm{a}}$ & $67.25 \pm 0.06^{\mathrm{b}}$ \\
F2 & $5.76^{\mathrm{b}}$ & $154.90 \pm 0.51^{\mathrm{h}}$ & $80.03 \pm 0.58^{\mathrm{e}}$ \\
F3 & $20.20^{\mathrm{f}}$ & $107.6 \pm 0.52^{\mathrm{f}}$ & $89.64 \pm 0.25^{\mathrm{g}}$ \\
F4 & $13.01^{\mathrm{d}}$ & $171.03 \pm 0.76^{\mathrm{i}}$ & $134.24 \pm 0.58^{\mathrm{j}}$ \\
F5 & $13.27^{\mathrm{d}}$ & $187.30 \pm 1.03^{\mathrm{j}}$ & $114.90 \pm 0.23^{\mathrm{i}}$ \\
F1.1 & $4.54^{\mathrm{a}}$ & $30.79 \pm 0.17^{\mathrm{d}}$ & $70.31 \pm 0.12^{\mathrm{c}}$ \\
F1.2 & $4.17^{\mathrm{a}}$ & $74.41 \pm 0.34^{\mathrm{e}}$ & $95.48 \pm 0.46^{\mathrm{h}}$ \\
F1.3 & $4.76^{\mathrm{a}}$ & $114.78 \pm 0.36^{\mathrm{g}}$ & $63.26 \pm 0.12^{\mathrm{a}}$ \\
\hline
\end{tabular}

Note: The numbers in the same column followed by the same letter are not significantly different $(\mathrm{P}<0.05)$, based on Duncan's multiple range test (DMRT)

Prediction of compounds contained in the active band was carried out qualitatively based on luminescence under UV light at 254 and $366 \mathrm{~nm}$. The F1.1 fraction has black spots at UV 254, the F1.1 and F1.2 fractions have blue spots at UV 366, while the F1.3 fraction is red (Figure 2).

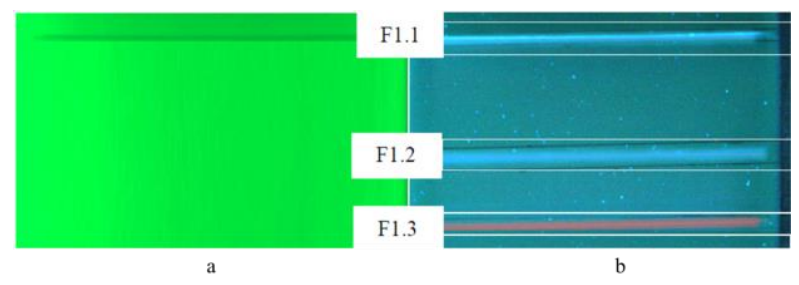

Figure 2. Preparative thin layer chromatogram in UV 254 (a) and UV 366 (b)

According to Markham, the blue color indicates the presence of flavone, flavanone, or flavonol compounds, red anthocyanidin compounds, and the greenness suggests the presence of auron and flavon compounds [36]. Based on this result, the active compounds as an antioxidant and antiglycation are included in the group of flavonoid compounds. The appearance of these colors refers to the appearance of flavonoid compounds. $X$. granatum is rich in flavonoids such as quercetin, kaempferol, catechin, and epicatechin and routine [19, 37].

\section{Conclusion}

The most active antiglycation and antioxidant activity in the methanol fraction with $\mathrm{IC}_{50}$ were $71.55 \mathrm{ppm}$ and $8.52 \mathrm{ppm}$, respectively. Antiglycation and antioxidant activity of the most active are methanol fraction> methanol extract> ethyl acetate fraction $>n$-hexane fraction. The methanol fraction contains an alkaloid, flavonoid, phenolic, and triterpenoid compounds. Subsequent fractionation of the methanol fraction guided by bioassay showed that sub-fraction 1 (F1) had the best antiglycation and antioxidant activity. Based on the spot chromatogram color formed at UV $366 \mathrm{~nm}$, the chemical component found in the most active fraction is the flavonoid group.

\section{References}

[1] Wendy del Dzib-Guerra, Fabiola Escalante-Erosa, Karlina Garcia-Sosa, Severine Derbre, Patricia Blanchard, Pascal Richomme and Luis PenaRodriguez, Anti-Advanced glycation end-product and free radical scavenging activity of plants from the yucatecan flora, Pharmacognosy Research, 8, 4, (2016), 276-280

https://doi.org/10.4103/0974-8490.188883

[2] Gugulethu Ndlovu, Gerda Fouche, Malefa Tselanyane, Werner Cordier and Vanessa Steenkamp, In vitro determination of the anti-aging potential of four southern African medicinal plants, BMC Complementary and Alternative Medicine, 13, 1, (2013), 304 https://doi.org/10.1186/1472-6882-13-304

[3] Izabela Grzegorczyk-Karolak, Krzysztof Gołąb, Jakub Gburek, Halina Wysokińska and Adam Matkowski, Inhibition of Advanced Glycation EndProduct Formation and Antioxidant Activity by Extracts and Polyphenols from Scutellaria alpina L. and S. altissima L, Molecules, 21, 6, (2016), https://doi.org/10.3390/molecules21060739

[4] Christiane Ott, Kathleen Jacobs, Elisa Haucke, Anne Navarrete Santos, Tilman Grune and Andreas Simm, Role of advanced glycation end products in cellular signaling, Redox Biology, 2, (2014), 411-429 https://doi.org/10.1016/j.redox.2013.12.016

[5] Chan-Sik Kim, Sok Park and Junghyun Kim, The role of glycation in the pathogenesis of aging and its prevention through herbal products and physical exercise, Journal of Exercise Nutrition \& Biochemistry, 21, 3, (2017), 55-61

https://doi.org/10.20463/jenb.2017.0027

[6] Mami Yokota, Hitoshi Masaki, Yuri Okano and Yoshihiro Tokudome, Effect of glycation focusing on the process of epidermal lipid synthesis in a reconstructed skin model and membrane fluidity of stratum corneum lipids, Dermato-Endocrinology, 9, 1, (2017), e1338992

https://doi.org/10.1080/19381980.2017.1338992

[7] Sakina Yagi, Natalia Drouart, Frédéric Bourgaud, Max Henry, Yves Chapleur and Dominique LaurainMattar, Antioxidant and antiglycation properties of Hydnora johannis roots, South African Journal of Botany, 84, (2013), 124-127 https://doi.org/10.1016/j.sajb.2012.10.006

[8] Ashok Shinde, Jayashree Ganu and Pankaja Naik, Effect of free radicals \& antioxidants on oxidative stress: a review, Journal of Dental and Allied Sciences, 1, 2, (2012), 63-66 https://doi.org/10.4103/2277-4696.159144

[9] Mohamad Gazali, Neviaty P Zamani and Irmanida Batubara, Potensi limbah kulit buah nyirih Xylocarpus granatum sebagai inhibitor tirosinase, DEPIK Jurnal Ilmu-Ilmu Perairan, Pesisir dan 
Perikanan, 3, 3, (2014), 187-194

https://doi.org/10.13170/depik.3.3.5711

[10] I. Batubara, L. K. Darusman, T. Mitsunaga, M. Rahminiwati and E. Djauhari, Potency of Indonesian medicinal plants as tyrosinase inhibitor and antioxidant agent, Journal of Biological Sciences, 10, 2, (2010), 138-144

http://dx.doi.org/10.3923/jbs.2010.138.144

[11] Latifah K.Ir Darusman, Irmanida Batubara and Lopolisa Catharina, Screening Marker Components of Tyrosinase Inhibitor From Xylocarpus Granatum Stem, Jurnal Kimia Valensi, 2, 3, (2011), 409-413 https://doi.org/10.15408/jkv.v2i3.111

[12] Udom Kokpol, Warinthorn Chavasiri, Santi Tippyang, Gaysorn Veerachato, Fenglin Zhao, Jim Simpson and Rex T. Weavers, A limonoid from Xylocarpus granatum, Phytochemistry, 41, 3, (1996), 903-905 https://doi.org/10.1016/0031-9422(95)00724-5

[13] Alison F. Stallings and Mary P. Lupo, Practical Uses of Botanicals in Skin Care, J Clin Aesthet Dermatol, 2, 1, (2009), 36-40

[14] Jeffrey B. Harborne, Phytochemical Methods: A Guide to Modern Techniques of Plant Analysis, Springer Netherlands, 2013

[15] Adawiah Adawiah, Kandungan Fitokimia dan Bioaktivitas Ekstrak Metanol Biji Palem Putri (Veitchia merillii), Jurnal Kimia Valensi, 2, 1, (2016), 63-70 http://dx.doi.org/10.15408/jkv.v2i1.3076

[16]Nasapon Povichit, Ampai Phrutivorapongkul, Maitree Suttajit and Pimporn Leelapornpisid, Antiglycation and antioxidant activities of oxyresveratrol extracted from the heartwood of Artocarpus lakoocha Roxb, Maejo International Journal of Science and Technology, 4, 3, (2010), 454461

[17] Deni Ramdani, Marjuki Majuki and Siti Chuzaemi, Pengaruh perbedaan jenis pelarut dalam proses ekstraksi buah mengkudu (Morinda citrifolia L.) pada pakan terhadap viabilitas protozoa dan produksi gas in-vitro, Jurnal Ilmu-Ilmu Peternakan, 27, 2, (2017), 54-62

https://doi.org/10.21776/ub.jiip.2017.027.02.07

[18] Buyung Rukmantara Susena Putra, Dewi Kusrini and Enny Fachriyah, Isolasi Senyawa Antioksidan dari Fraksi Etil Asetat Daun Tempuyung (Sonchus arvensis L), Jurnal Kimia Sains dan Aplikasi, 16, 3, (2013), 69-70

https://doi.org/10.14710/jksa.16.3.69-72

[19] Irmanida Batubara, Ummi Zahra, Latifah K. Darusman and Akhirudin Maddu, Minyak atsiri daun zingiberaceae sebagai antioksidan dan antiglikasi, Indonesian Journal of Essential Oil, 1, 1, (2016), 44-52 http://dx.doi.org/10.21776/ub.ijeo.2016.001.01.05

[20]Agnieszka Piwowar, Anna Rorbach-Dolata and Izabela Fecka, The Antiglycoxidative Ability of Selected Phenolic Compounds-An In Vitro Study, Molecules, 24, 15, (2019), https://doi.org/10.3390/molecules24152689
[21] Shaikh J. Uddin, Lutfun Nahar, Jamil A. Shilpi, Mohammad Shoeb, Tomasz Borkowski, Simon Gibbons, Moira Middleton, Maureen Byres and Satyajit D. Sarker, Gedunin, a limonoid from Xylocarpus granatum, inhibits the growth of CaCo-2 colon cancer cell line In Vitro, Phytotherapy Research, 21, 8, (2007), 757-761

https://doi.org/10.1002/ptr.2159

[22]Musa Chacha, Flavanol derivatives with antioxidant activity from the stem bark of Xylocarpus granatum, International Journal of Biological and Chemical Sciences, 4, 2, (2010), 371-376

http://dx.doi.org/10.4314/ijbcs.v4i2.58127

[23] Shijie Du, Mingan Wang, Wen Zhu and Zhaohai Qin, A new fungicidal lactone from Xylocarpus granatum (Meliaceae), Natural Product Research, 23, 14, (2009), 1316-1321

https://doi.org/10.1080/14786410902726183

[24]Sweta Misra, Meenakshi Verma, Sunil Kumar Mishra, Shishir Srivastava, Vijai Lakshmi and Shailja MisraBhattacharya, Gedunin and photogedunin of Xylocarpus granatum possess antifilarial activity against human lymphatic filarial parasite Brugia malayi in experimental rodent host, Parasitology Research, 109, 5, (2011), 1351

https://doi.org/10.1007/s00436-011-2380-x

[25]Qiang Gao, Yuan Gao, Han Song, Jianli Li, Yibing Wu, Xiaowei Shi, Haishui Shi and Yuxia Ma, Cipadesin A, a bioactive ingredient of Xylocarpus granatum, produces antidepressant-like effects in adult mice, Neuroscience Letters, 633, (2016), 33-39 https://doi.org/10.1016/j.neulet.2016.08.062

[26]Xi Yin, Xin Li, Yaoguang Hao, Yiwen Zhao, Jinghong Zhou and Haishui Shi, Xylocarpin H, a Limonoid of Xylocarpus granatum, Produces Antidepressant-Like Activities in Mice, Journal of Behavioral and Brain Science, 5, 11, (2015), 524-532 https://doi.org/10.4236/jbbs.2015.511050

[27]Yi-Guo Dai, Jun Wu, Krishna Pillai Padmakumar and Li Shen, Sundarbanxylogranins A-E, five new limonoids from the Sundarban Mangrove, Xylocarpus granatum, Fitoterapia, 122, (2017), 85-89 https://doi.org/10.1016/j.fitote.2017.08.013

[28]Haroon Ahmad, Ibrar Khan and Wagma Nisar, Antioxidation and Antiglycation Properties of Bunium Bulbocastanum Fruits Various Fractions and its Possible Role in Reducing Diabetes Complication and Ageing, Vitamins \& Minerals, 3, 1, (2014), 1000118 https://doi.org/10.4172/2376-1318.1000118

[29]Ummi Zahra, Yuni Kartika, Irmanida Batubara, Latifah K Darusman and Akhiruddin Maddu, Screening the potency of Zingiberaceae leaves as antioxidant and antiaging agent, Nusantara Bioscience, 8, 2, (2016), 221-225 https://doi.org/10.13057/nusbiosci/no80214

[30]Luc Séro, Lionel Sanguinet, Patricia Blanchard, T. Bach Dang, Sylvie Morel, Pascal Richomme, Denis Séraphin and Séverine Derbré, Tuning a 96-Well Microtiter Plate Fluorescence-Based Assay to Identify AGE Inhibitors in Crude Plant Extracts, Molecules, 18, 11, (2013), https://doi.org/10.3390/molecules181114320 
[31] Philip Molyneux, The use of the stable free radical diphenylpicrylhydrazyl (DPPH) for estimating antioxidant activity, Songklanakarin Journal of Science and Technology (SJST), 26, 2, (2004), 211-219

[32]Dita Widia Ningrum, Dewi Kusrini and Enny Fachriyah, Uji Aktivitas Antioksidan Senyawa Flavonoid dari Ekstrak Etanol Daun Johar (Senna siamea Lamk), Jurnal Kimia Sains dan Aplikasi, 20, 3, (2017), 123-129 https://doi.org/10.14710/jksa.20.3.123-129

[33] Haslina Haslina and Murtiari Eva, Extract Corn Silk with Variation of Solvents on Yield, Total Phenolics, Total Flavonoids and Antioxidant Activity, Indonesian Food and Nutrition Progress, 14, 1, (2017), 21-28 https://doi.org/10.22146/ifnp.24280

[34]Askal Maimulyanti and Anton Restu Prihadi, Chemical composition of essential oil and hexane extract and antioxidant activity of various extracts of Acmella uliginosa (Sw.) Cass flowers from Indonesia, Agriculture and Natural Resources, 50, 4, (2016), 264269 https://doi.org/10.1016/j.anres.2015.11.002

[35] Do Hoang Thu Trang, Hoang Le Son and Phung Van Trung, Investigation on the in vitro antioxidant capacity of methanol extract, fractions and flavones from Oroxylum indicum Linn bark, Brazilian Journal of Pharmaceutical Sciences, 54, 1, (2018), 1-7 http://dx.doi.org/10.1590/s217597902018000117178

[36]K.R. Markham, Cara Mengidentifikasi Flavonoid, P. Kosasih, ITB, Bandung, 1988

[37] Swagat Kumar Das, Dibyajyoti Samantaray, Jayanta Kumar Patra, Luna Samanta and Hrudayanath Thatoi, Antidiabetic potential of mangrove plants: a review, Frontiers in Life Science, 9, 1, (2016), 75-88 https://doi.org/10.1080/21553769.2015.1091386 